\title{
Produktivitas Enzim Lignase Dari Jamur Marasmius Sp Dan Efektifitasnya Dalam Mendegradasi Lignin Pada Media Serat Sawit Untuk Pakan Ternak Ruminansia The Productivity of Lignase of Mashroom of Marasmius Sp And It's Effectifity In Lignin Degradation In Oil Palm Fiber For Ruminant Feed
}

\author{
Endri Musnandar dan Fachroerozi Hoesni \\ Laboratorium Produksi Ternak, Fakultas Peternakan \\ Jl. Raya Jambi-Ma.Bulian km 15, Mendalo Darat Jambi \\ Email: endri.musnandar@yahoo.com
}

\begin{abstract}
Intisari
Penelitian ini bertujuan untuk mengetahui optimalisasi produksi enzim ekstraseluler (lignin) dan efektivitasnya dalam memecah lignin dalam media serat sawit. Tujuan lainya yaitu mengetahui perubahan gizi media serat sawit yang ditandai dengan peningkatan protein, penurunan kadar serat, dan produksi gula reduksi. Penelitian dilakukan dengan metode eksperimen dengan rancangan acak lengkap pola faktorial 3x3. Faktor pertama yaitu sumber energi yaitu Dedak, molases, dan poles. Faktor kedua, yaitu tingkat urea dalam substrat, masing-masing $0 \%\left(\mathrm{U}_{0}\right), 1 \%\left(\mathrm{U}_{1}\right)$, dan $2 \%\left(\mathrm{U}_{2}\right)$. Seluruhnya terdapat 9 perlakuan, masing-masing perlakuan diulang empat kali. Peubah yang diamati yaitu panjang miselium. Data yang diperoleh dianalisis sidik ragam, bila analisis ragam menunjukkan perbedaan dilanjutkan dengan Uji DMRT. Perlakuan yang menghasilkan panjang miselium tertinggi (pertumbuhan terbaik) kemudian diambil data per periode pertumbuhan untuk dianalisis kandungan gizi, kadar lignin, gula pereduksi, dan kandungan enzim lignasenya. Data yang diperoleh dianalisis menggunakan One Way Anova. Hasil penelitian menunjukkan bahwa pertumbuhan terbaik yaitu pada media serat sawit yang diberi urea $1 \%$ dan poles $10 \%\left(\mathrm{U}_{1} \mathrm{P}_{10}\right)$ dengan panjang miselium $94,25 \mathrm{~mm}$ dan yang terendah pada pemberian Urea $0 \%$ dan Dedak $10 \%\left(\mathrm{U}_{0} \mathrm{D}_{10}\right)$ yaitu $30 \mathrm{~mm}$. Kandungan gizi pada periode pertumbuhan V lebih baik dibandingkan periode lainnya dengan kandungan protein $7,4085 \%$, dan yang terendah pada periode pertumbuhan I yaitu 3,5152\%, sedangkan kandungan ADF paling rendah juga pada periode $\mathrm{V}$ yaitu 10,66\% dan tertinggi pada periode I yaitu $19,30 \%$. Kandungan lignin terendah diperoleh pada periode pertumbuhan V yaitu $7,23 \%$. Begitu juga produksi gula pereduksi tertinggi dicapai pada periode $\mathrm{V}$ yaitu.7,485 mg/g. Disimpulkan bahwa aktivitas enzim dan kandungan gizi terbaik pada serat sawit yang difermentasi pada fase kelima atau setelah difermentasi selama 20 hari.
\end{abstract}

Kata kunci : Marasmius sp, lignase, gula reduksi, lignin

\begin{abstract}
The aim of this experiment was to reveal the optimalization of the production of extracellular enzyme (lignin) and it's efectivity in lysing lignin in media of oil palm fiber and it'seffect on the increase of protein content, the ddecrease of fiber content and the production of reduction sugar. The design of experiment was Completely Randomized Desing in factorial arranggement $(3 \times 3)$ with the first factor of energy source (ricebran, molases, dan poles) and the second factor of urea level in substrates $(0,1$, and $2 \%$ with four replication for each treatment. The parameter measured was meselium length. Data was analysed by using ANOVA and followed with Duncant Test. The best treatment, producing the longest micelium, was periodically analysed for teh content of lignin, reduction sugar, lignase enzyme. Results showed that the best growth of miselium was on oil palm fiber media treated with $1 \%$ of urea and $10 \%$ of poles $\left(\mathrm{U}_{1} \mathrm{P}_{10}\right)$ with the miselium length of $94,25 \mathrm{~mm}$ and the worse of those was on treatment $\mathrm{U}_{0} \mathrm{D}_{10}$ with $30 \mathrm{~mm}$ length. The nutrient content on growing period of $\mathrm{V}$ was the best
\end{abstract}


among other period with the protein content of $7.4085 \%$, and the lowest was on period I with the protein content of $3.5152 \%$, while the lowest content of ADF was on period V with the ADF content of $10.66 \%$ and the highest was on period I with the ADF content of $19.30 \%$. The loewest content of ligni was on period $\mathrm{V}$ wth the content of $7.23 \%$. The highest production of reduction sugar was on period $\mathrm{V}$ with the content of $7.485 \mathrm{mg} / \mathrm{g}$. It could be concluded that the enzyme activity and the best nutrient content on oil palm media fermented on the fifth fase with the length of incubation time of 20 days.

Key word : Marasmius sp, lignase, sugar reduction, lignin

\section{Pendahuluan}

Serat sawit diharapkan dapat menunjang bahkan menggantikan fungsi rumput sebagai bahan pakan sumber serat (sumber energi) bagi ternak ruminansia. Kandungan nutrisi serat sawit hampir mendekati kandungan nutrisi rumput, baik kadar protein kasarnya maupun kadar serat kasar dan mineralnya. Namun pemanfaatan serat sawit sebagai bahan pakan ternak terbatas karena kadar lignin yang terlalu tinggi. Kadar lignin yang tinggi dalam ransum dapat menyebabkan gangguan pada proses pencernaan, oleh karena itu untuk meningkatkan nilai manfaat serat sawit sebagai bahan pakan ternak harus diupayakan agar kadar ligninnya dapat diturunkan atau bahkan dihilangkan.

Upaya untuk mengolah limbah berserat tinggi seperti serat sawit agar dapat dimanfaatkan oleh ternak terutama oleh ternak ruminansia yang memiliki kemampuan mencerna serat relatif tinggi, telah banyak dilakukan. Diantara upaya tersebut adalah dengan menggunakan zat kimia seperti asam kuat atau basa kuat. Maksud perlakuan tersebut adalah agar ikatan kimia atau struktur fisik serat yang kuat dapat diuraikan. Namun cara ini dipandang belum memenuhi harapan karena harganya mahal dan hasilnya kurang memuaskan, sehingga tidak menguntungkan.

Alternatif lain dalam upaya menurunkan anti nutrisi dengan cara biologis yaitu dengan memanfaatkan aktivitas mikroba karena diharapkan mikroba dapat mereput (mendegradasi) serat secara lebih ekonomis dan hasilnya dapat lebih bermanfaat. Penggunaan mikroba untuk meningkatkan manfaat limbah pertanian telah dilakukan terhadap bungkil biji kapok, jerami padi, dan ampas tebu. Hasilnya, limbah tersebut yang tadinya kurang bermanfaat menjadi berdayaguna karena meningkatnya nilai nutrisi (Rusdi, 1992; Santosa, 1996; Tarmidi, 1999). Bakteri dan fungi merupakan mikroba yang mampu mereput serat, bahkan setengah dari jenis fungi memiliki kemampuan mereput serat.

Salah satu fungi yang dapat mereput serat (lignin) adalah jamur Marasmius sp. yaitu jamur dari kelompok lignophilik yang berasal dari negara Colombia, namanya belum begitu populer karena masih dianggap baru di Indonesia. Hasil penelitian mengenai jamur Marasmius sp. masih sangat terbatas. Jamur ini memiliki kemampuan memproduksi enzim yang dapat memecah bahan organik yang kandungan lignin dan selulosanya tinggi. Jamur Marasmius $s p$. untuk mereput (mendegradasi) serat secara optimal memerlukan 
energi dan protein serta waktu yang mencukupi. Jamur ini dapat mendegradasi lignin karena diharapkan dapat menghasilkan enzim Lignin Peroksidase (LiP) yang dapat mengkatalisis proses oksidasi dari cincin aromatic lignin (Harvey, dkk., 1996) dan menghasilkan enzim MnP yaitu enzim yang dapat mengatifkan proses okdidasi dalam substrat (Caamarero, dkk., 1996).

Untuk menunjang partumbuhan sel bodi jamur yang lebih cepat perlu disediakan sumber nitrogen, salah satunya yaitu urea. Urea selain sumber nitrogen untuk mempercepat pertumbuhan jamur juga dapat merenggangkan ikatan karbon dalam serat sawit sehingga kerja jamur dalam memecah serat lebih efektif. Fermentasi serat sawit oleh jamur Marasmius sp. diharapkan dapat mereput (mendegradasi) lignin menjadi lebih sederhana, zat lebih sederhana ini akan lebih mudah dicerna dan diserap oleh sistem pencernaan ternak sehingga nilai kecernaan dan nilai hayati bahan pakan akan meningkat. Melalui proses fermentasi selain akan dihasilkan berupa serat sawit terfermentasi juga akan tercakup sel tubuh mikroba dan enzim yang mengandung protein serta metabolit-metabolit lainya. Dengan demikian proses fermentasi dapat menghasilkan produk akhir berupa serat sawit terfermentasi dengan kadar protein yang lebih baik serta tingkat kecernaan yang lebih tinggi. Melalui proses ini serat sawit dapat ditingkatkan nilai gunanya sebagai bahan pakan ternak ruminansia sehingga dapat menggantikan sebagian fungsi rumput. Keberhasilan substitusi rumput oleh serat sawit terfermentasi dapat menjadikan bahan pakan untuk ternak ruminansia akan terjaga sepanjang tahun dengan kualitas yang memadai, sehingga dapat mendorong pengembangan atau peningkatan produksi ternak ruminansia. Namun, bagaimana laju pertumbuhan jamur Marasmius sp. pada serat sawit dan bagaimana bahan bioaktif atau enzim lignase diproduksi serta efektifitas enzim mengurai lignin belum diketahui.

\section{Metode Penelitian}

\section{Pelaksanaan Penelitian}

Penelitian ini dilaksanakan di laboratorium dengan 2 tahap penelitian yaitu:

1. Penelitian dilakukan di Laboratorium untuk mempelajari pertumbuhan (panjang miselium) Jamur Marasmius sp dengan media serat sawit dengan berbagai imbuhan sumber energi dan urea berbeda.

2. Penelitian untuk mempelajari dan menganalisis produktivitas enzim lignase, efektivitas enzim lignase dan produksi gula reduksi.

\section{Pembuatan Substrat Berbahan Serat Sawit}

Serat sawit dikeringkan dengan cara dijemur dibawah sinar matahari selama satu hari (sampai kadar air sekitar 10\%). Serat kelapa sawit kering digiling menggunakan gilingan yang memiliki saringan Merk FFC No.2 (diameter $0,75 \mathrm{~mm}$ ). Sementara itu disiapkan urea $0 \%$ dan $1 \%$ dari bobot serat sawit dan larutkan dalam aquades $80 \%$ dari berat bobot sawit. Urea yang telah larut dalam aqudes tersebut disemprotkan pada serat sawit kering giling dan diaduk sampai 
rata (homogen) hasilnya disebut media. Serat sawit yang telah tercampur dengan urea (media) dimasukkan pada cawan petri. Media pada cawan petri disterilkan dengan autoclave pada tekanan 1 atmosphere, temperatur $121^{\circ} \mathrm{C}$, selama 60 menit. PDA yang telah ditumbuhi jamur Marasmius sp. diambil menggunakan pelubang gabus (diameter $3 \mathrm{~mm}$ ). Jamur Marasmius sp. tersebut ditanamkan pada media di Laminar agar bebas kontaminasi. Cawan petri berisi media dan jamur Marasmius $s p$. disimpan di lemari inkubasi.

Tahap I : Pengaruh tingkat urea dan sumber energi dalam substrat terhadap diameter miselium jamur Marasmius sp..

Tujuan : untuk mengetahui diameter miselium jamur pada tingkat urea dan sumber energi berbeda dalam substrat. Diameter miselium menggambarkan petumbuhan jamur.

Alat dan bahan

- Cawan petri, untuk pembiakan jamur pada PDA dan serat sawit.

- Timbangan digital Merk Chiyo kapasitas 3000 gram, akurasi 1 gram, buatan Jepang, untuk menimbang serat sawit sebelum disterilkan.

- Timbangan analitik Merk Ultra X tipe UX 210, kapasitas maksimum 300 gram akurasi 0,001 gram buatan Jerman, untuk menimbang urea dan penyusutan media setelah biodegradasi.

- Autoclave, untuk mensterilkan alat dan media.

- Laminar, lemari steril tempat menanam jamur agar tidak terkontaminasi.
- lemari inkubasi, untuk menyimpan cawan petri yang telah diperlakukan.

- Penggiling dengan saringan FFC No.2 (0,75 mm), untuk menggiling dan menyaring serat sawit sesuai ukuran.

- mistar $10 \mathrm{~cm}$, untuk mengukur panjang miselium.

- Serat kelapa sawit diperoleh dari PT. Indosawit, Kab. Tanjab-Jambi

- Jamur Marasmius sp. diperoleh dari Lab. Mikologi PPAU Ilmu Hayati ITB, Bandung.

- Urea, dedak, molases, polish, dan aquades

- Potato Dextrose Agar (PDA).

\section{Rancangan percobaan}

Digunakan metode eksperimen dengan rancangan acak lengkap pola factorial $3 \times 3$. Faktor pertama yaitu sumber energi yaitu Dedak, molases, dan polish.. Faktor kedua, yaitu tingkat urea dalam substrat, masingmasing $0 \%\left(\mathrm{U}_{0}\right), 1 \%\left(\mathrm{U}_{1}\right)$, dan $2 \%\left(\mathrm{U}_{2}\right)$. Seluruhnya terdapat 9 perlakuan, masing-masing perlakuan diulang empat kali. Data yang diperoleh dianalisis sidik ragam, bila analisis sidik ragam menunjukkan perbedaan dilanjutkan dengan Uji Duncan (Steel dan Torrie, 1981).

\section{Peubah Yang Diukur}

Panjang miselium diukur menurut metode dari Garraway dan Evans (1984). Setiap periode pertumbuhan kemudian diambil sampel untuk diukur kandungan gula pereduksinya untuk memperkirakan akrivitas enzim pada setiap periode pertumbuhan jamur. Prosedur analisis gula pereduksi mengacu pada Ahmadi, dkk. (2000) 
Tahap II : Pengaruh tingkat pertumbuhan jamur Marasmius sp.. terhadap gizi serat sawit, produktivitas dan efektivitas enzim lignase

Setiap periode pertumbuhan jamur diambil sampel untuk dianalisis kandungan lignin, kandungan gizi.. Selanjutnya dilakukan analisis kandungan gula pereduksi untuk melihat aktivitas enzim.

-Kandungan gizi dan kandungan lignin metode Van Soest (1966).

-Kandungan protein sebenarnya (true protein), menggunakan metoda HPLC. -Aktivitas enzim lignase dan efektivitasnya, menggunakan metode Tien dan Kirk (1984) serta Limori, dkk. (1998)

Data dianalisis dengan uji statistik yang sesuai menggunakan software program SPSS ver.11 (2002).

\section{Hasil Dan Pembahasan}

\section{Diameter Miselium}

Garraway dan Evans, (1984) menyatakan bahwa panjang miselium merupakan gambaran pertumbuhan jamur tersebut. Dengan demikian, semakin panjang miselium jamur maka pertumbuhan jamur tersebut semakin baik. Pertumbuhan jamur yang semakin baik menggambarkan bahwa nutrisi di dalam media mencukupi dan sesuai dengan kebutuhan jamur, selain lingkungan yang cocok untuk pertumbuhannya. Pertumbuhan jamur pada setiap perlakuan dapat dilihat pada Gambar 1 .

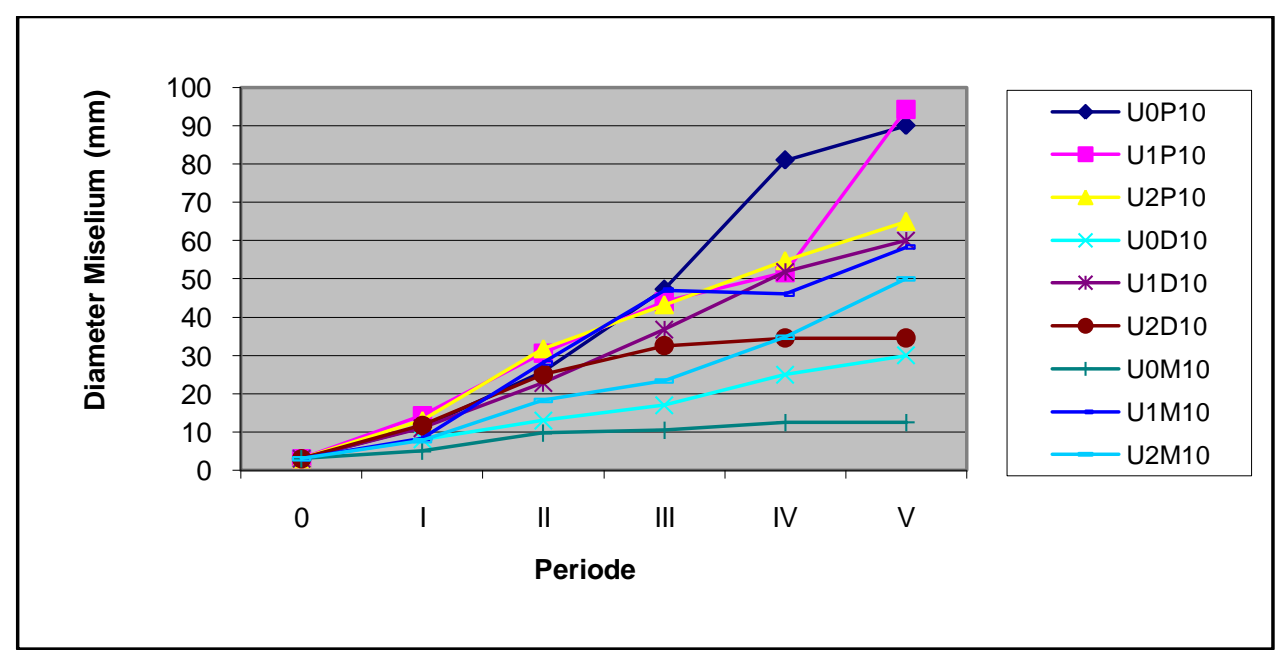

Gambar 1. Pertumbuhan jamur Marasmius sp pada setiap perlakuan dan periode

Berdasarkan data pada Gambar 1 dapat dilihat bahwa perlakuan $\mathrm{U}_{1} \mathrm{P}_{10}$ memberikan pertumbuhan jamur tertinggi, berarti pemberian urea $1 \%$ dicampur dengan polish 10\% akan menghasilkan pertumbuhan jamur yang lebih otimal. Kondisi ini menunjukkan bahwa pemberian poles $10 \%$ dapat menyediakan energy yang lebih baik daripada pemberian sumber 
energi lainnya. .Hal ini dapat terjadi karena poles mengandung nutrisi yang lebih lengkap dibandingkan sumber energy lainnya, selain itu perombakan poles sebagai sumber energi agak lambat sehingga sumber energi tersedia lebih lama (Fakhri, 2008). Sedangkan penambahan molasses sebagai sumber energi dalam substrat diduga lebih cepat terurai sehingga pemanfaatannya sebagai sumber energi belum maksimal. Fakhri (2008) melaporkan hasil penelitiaanya bahwa pemberian OPF (oil Palm Frond) ditambah molases, perombakan serat kasar OPF sangat kecil dan $\mathrm{pH}$ OPF-nya masih tinggi, yang menunjukkan bahwa tingkat fermentasi dan jumlah mikrobanya kecil. Pemberian dedak dalam substrat sebagai sumber energi bagi mikroba sebenarnya cukup baik karena harganya relatif murah, namun dedak kandungan seratnya masih tinggi sehingga mikroba dalam substrat tidak dapat menggunakan sumber energi dengan lebih optimal. Hasil pengukuran panjang miselium pada berbagai tingkat urea dan sumber energi dapat dilihat pada Tabel 1.

Tabel 1. Panjang miselium pada berbagai tingkat urea dan sumber energy ( $\mathrm{mm})$

\begin{tabular}{|c|c|c|c|c|c|}
\hline \multirow{2}{*}{ Urea } & \multicolumn{3}{|c|}{ Sumber Energi } & \multirow{2}{*}{ Jumlah } & \multirow{2}{*}{ Rataan } \\
\hline & $\mathrm{D}$ & $\mathrm{P}$ & $\mathrm{M}$ & & \\
\hline U0 & 30 & 90 & 52.50 & 172.50 & $57.50^{\mathrm{b}}$ \\
\hline U1 & 60 & 94.25 & 58.25 & 212.50 & $70.83^{a}$ \\
\hline U2 & 34.50 & 65 & 50 & 149.50 & $49.83^{c}$ \\
\hline Jumlah & 124.50 & 249.30 & 160.80 & & \\
\hline Rataan & $41.50^{c}$ & $83.08^{a}$ & $53.58^{\mathrm{b}}$ & & \\
\hline
\end{tabular}

Keterangan : Superskrip dibelakang angka berbeda pada kolom atau baris rataan menunjukkan berbeda nyata $(\mathrm{P}<.05)$

Berdasarkan data pada Tabel 1 dapat dilihat bahwa pemberian urea $1 \%$ memberikan rataan pertumbuhan yang terbaik yaitu 70,83 mm. Kondisi ini karena urea sebagai sumber protein sangat diperlukan oleh jamur untuk pertumbuhannya (miselium), namun urea juga merupakan zat yang cepat terurai menjadi amoiniak sehingga apabila urea terlalu banyak dalam substrat akn meracuni jamur sehingga pertumbuhannya terhambat (Musnandar, 2003). Pada Tabel di atas juga tampak bahwa sumber energi terbaik yaitu poles dengan rataan panjang miselium 83,08 $\mathrm{mm}$. Kondisi ini disebabkan poles merupakan bahan pakan yang cukup baik zat gizinya dibandingkan dedak dan molases sehingga sangat baik bagi pertumbuhan mikroba (Fakhri, 2006).

\section{Kandungan Gizi}

Berdasarkan

kecepatan pertumbuhan pada penelitian tahap 1 menunjukkan bahwa pertumbuhan tertinggi adalah pada perlakuan $\mathrm{U}_{1} \mathrm{P}_{10}$. Oleh karena itu, dilakukan penelitian lebih lanjut terhadap perlakuan $\mathrm{U}_{1} \mathrm{P}_{10}$ dengan melakukan analisis terhadap kandungan gizi pada setiap periode pertumbuhannya. Hasil pengukuran kandungan gizi serat sawit yang mendapat perlakuan $\mathrm{U}_{1} \mathrm{P}_{10}$ tertera pada Tabel 2. 
Tabel 2. Nilai gizi serat sawit pada setiap periode pertumbuhan

\begin{tabular}{lrrrrc}
\hline \multirow{2}{*}{ Fase Pertumbuhan } & \multicolumn{5}{c}{ Gizi $(\%)$} \\
\cline { 2 - 6 } & \multicolumn{1}{c}{ BK } & \multicolumn{1}{c}{ ADF } & NDF & Lignin & Protein \\
\hline I & $34.87^{\mathrm{b}}$ & $19.31^{\mathrm{a}}$ & $25.64^{\mathrm{b}}$ & $9.97^{\mathrm{a}}$ & $3.52^{\mathrm{c}}$ \\
II & $35.62^{\mathrm{b}}$ & $13.86^{\mathrm{b}}$ & $29.64^{\mathrm{a}}$ & $9.43^{\mathrm{a}}$ & $4.36^{\mathrm{ab}}$ \\
III & $42.43^{\mathrm{a}}$ & $13.26^{\mathrm{b}}$ & $31.50^{\mathrm{a}}$ & $8.95^{\mathrm{ab}}$ & $4.34^{\mathrm{ab}}$ \\
IV & $43.82^{\mathrm{a}}$ & $11.06^{\mathrm{c}}$ & $31.36^{\mathrm{a}}$ & $7.58^{\mathrm{b}}$ & $6.20^{\mathrm{a}}$ \\
V & $43.11^{\mathrm{a}}$ & $10.67^{\mathrm{c}}$ & $28.87^{\mathrm{ab}}$ & $7.23^{\mathrm{b}}$ & $7.41^{\mathrm{a}}$ \\
\hline
\end{tabular}

Keterangan : Superskrip berbeda dibelakang angka pada kolom yang sama menunjukkan berbeda nyata $(\mathrm{P}<.05)$

Tabel 2 menunjukkan bahwa persentase protein pada periode pertumbuhan $\mathrm{V}$ ternyata kandungan proteinnya paling tinggi yaitu 7,4085\%, hal ini menunjukkan bahwa walaupun periode pertumbuhan sudah mulai menurun tetapi kandungan proteinnya tetap tinggi, hal ini diduga karena masa tubuh mikroba yang cukup tinggi Garraway dan Evans, (1984) menyatakan bahwa dalam tubuh mikroba terkandung protein. Sehingga apabila masa tubuh mikroba tinggi maka kandungan protein dalam substrat juga akan tinggi. Pada Tabel 2 juga dapat dilihat bahwa kandungan ADF pada periode pertumbuhan $\mathrm{V}$ telah menurun cukup drastis dibandingkan dengan periode pertumbuhan I. Terlihat kecenderungan bahwa kandungan ADF serat sawit yang telah difermentasi pada berbagai periode pertumbuhan seluruhnya lebih rendah dari kandungan ADF serat sawit tanpa fermentasi. Kandungan ADF pada penelitian ini jauh lebih rendah dari hasil penelitian Alimin dan Bejo (1995) yang menyatakan bahwa kandungan ADF serat sawit sebesar $55,6 \%$, bahkan lebih rendah dari kandungan ADF dalam empulur pelepah sawit sebesar 40,24\% (Fakhri, 2006). Rendahnya kandungan ADF pada seluruh periode pertumbuhan menunjukkan bahwa telah terjadi fermentasi oleh jamur yang menyebabkan terurainya serat di dalam serat sawit. Periode pertumbuhan $\mathrm{V}$ kandungan ADF nya paling rendah, hal ini diduga karena pada periode pertumbuhan $\mathrm{V}$ merupakan periode pertumbuhan tertinggi ditandai dengan panjang miselium yang paling panjang. Pada saat pertumbuhan tinggi tentu dibutuhkan zat makanan untuk pertumbuhannya sehingga jamur mengurai serat dalam serat sawit lebih cepat. Musnandar (2003), serta Hendritomo (1995) menyatakan bahwa jamur Marasmius sp dapat menghasilkan enzim ekstra seluler yang dapat mendegradasi serat, sehingga kadar serat di dalam substrat akan menurun.

Persentase Bahan kering juga meningkat sampai periode pertumbuhan $\mathrm{V}$. Hal ini karena pada periode pertumbuhan $\mathrm{V}$ merupakan periode dengan diameter miselium koloni terpanjang sehingga masa bodi jamur di dalam substrat menjadi tinggi. Masa bodi mikroba yang tinggi tentu akan meningkatkan kadar bahan kering dari serat sawit fermentasi.

\section{Kandungan Lignin}

Kandungan lignin dalam bahan makanan merupakan pembatas karena dapat menghambat kecernaan. Arora 
(1998) menyatakan bahwa kandungan lignin dalam ransum lebih 10\% akan menyebabkan gangguan pencernaan. Oleh karena itu, bahan pakan yang baik disarankan memiliki kandungan lignin kurang dari 10\%. Kandungan lignin pada serat sawit yang telah difermentasi oleh jamur Marasmius sp. pada setiap periode pertumbuhan dapat dilihat pada Tabel 2 dan kecenderungan perubahannya dapat dilihat pada Gamgar 2.

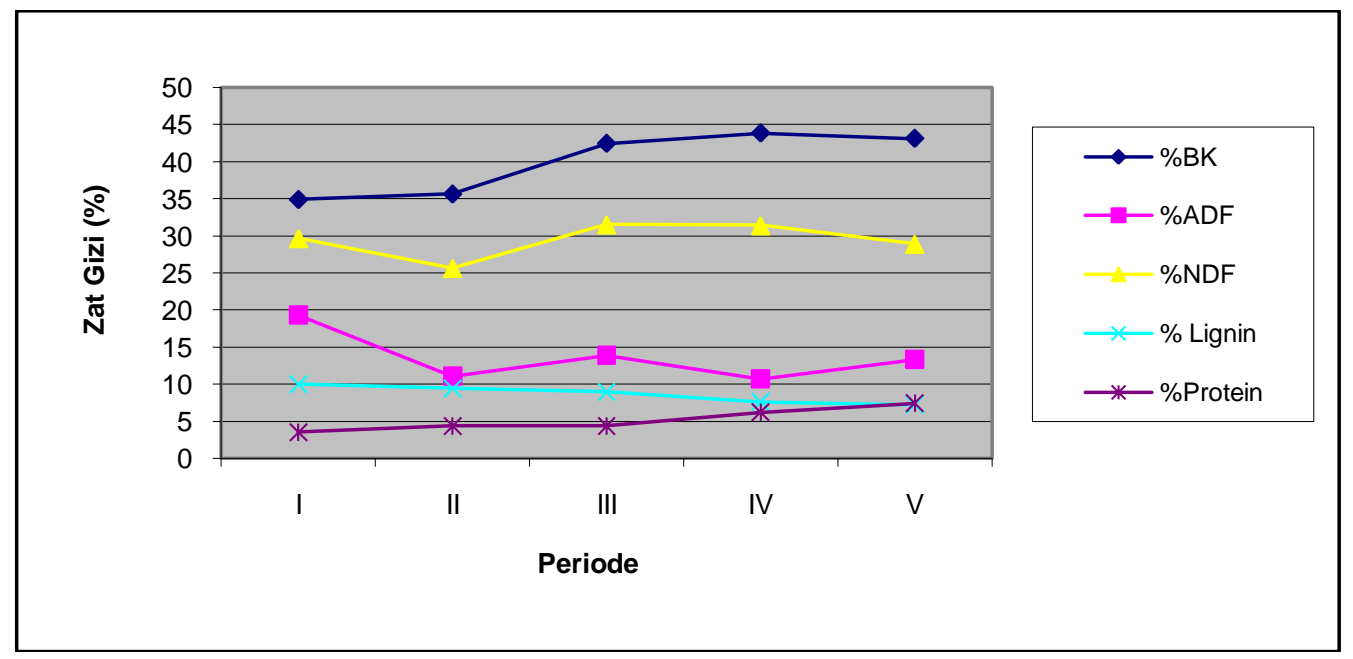

Gambar 2. Zat gizi yang dikandung serat sawit fermentasi pada tiap periode pertumbuhan

Pada Gambar 2 tampak bahwa persentase lignin menurun setiap periodepertumbuhan. Keadaan ini karena selama pertumbuhannya jamur menguraikan serat yang terkandung di dalam serat sawit termasuk lignin untuk kebutuhan metabolisme tubuhnya. Persentase lignin serat sawit pada penelitian ini lebih rendah daripada hasil penelitian Musnandar (2003) yang menyatakan bahwa kandungan lignin serat sawit fermentasi adalah $11,37 \%$. Perbedaan ini dapat disebabkan oleh imbuhan yang berbeda, suhu, maupun lama inkubasi. Namun, secara keseluruhan menunjukkan penurunan kadar lignin dalam serat sawit. Kadar lignin yang jauh menurun pada serat sawit fermentasi ini karena jamur Marasmius sp merupakan jamur lignophilik, jamur yang senang pada lingkungan yang mengandung lignin. Artiningsih (2006) menyatakan bahwa jamur lignolitik atau yang dapat mensek-resikan enzim lignase akan lebih cepat menurunkan kadar lignin dalam media dibandingkan jamur lainnya.

\section{Produksi Gula Reduksi}

Kandungan gula reduksi dalam media serat sawit yang difermentasi menunjukkan bahwa terjadi aktivitas penguraian serat oleh enzim menjadi gula-gula yang lebih sederhana untuk pertumbuhan jamur. Dengan demikian, kandungan gula reduksi yang tinggi dalam media menun-jukkan produksi enzim yang lebih tinggi dari lainnya. Arora dan Sandhu (1985) yang disitasi oleh Artiningsih (2006) menyatakan bahwa gula lebih diperlukan untuk pembentukan biomasa jamur daripada produksi enzim lignolitik. Kandungan gula reduksi pada setiap periode pertumbuhan dapat dilihat pada Tabel 3. 
Tabel 3. Kandungan gula reduksi pada serat sawit pada tiap periode pertumbuhan

\begin{tabular}{|c|c|c|c|c|c|c|}
\hline Ulangan & & Fase I & Fase II & FaseIII & Fase IV & Fase V \\
\hline & 1 & 2.8143 & 3.6753 & 3.7689 & 4.1225 & 8.3998 \\
\hline & 2 & 3.2461 & 4.1142 & 4.9163 & 4.6604 & 7.5759 \\
\hline & 3 & 2.8948 & 3.7347 & 5.1298 & 4.1515 & 6.4490 \\
\hline & 4 & 3.0302 & 3.8948 & 4.3426 & 4.3915 & 7.9879 \\
\hline & 5 & 3.0705 & 3.9245 & 5.0231 & 4.4060 & 7.0125 \\
\hline Jumlah & & 15.0559 & 19.3434 & 23.1807 & 37.4250 & 21.7318 \\
\hline Rataan & & $3.0112^{\mathrm{d}}$ & $3.8687 \mathrm{c}$ & $4.6361^{b c}$ & $4.3464^{b}$ & $7.4850^{\mathrm{a}}$ \\
\hline
\end{tabular}

Tabel 3 menunjukkan bahwa kandunga gula reduksi pada serat sawit fermentasi berkisar 3,0112-7,4850 $\mathrm{mg} / \mathrm{g}$. Kandunga gula reduksi ini jauh lebih rendah dari kandungan gula reduksi pada sabut hasil penelitian Dewi (2002) yaitu 27,42 mg/g substrat. Perbedaan ini dapat disebabkan oleh perbedaan jenis jamur maupun substart yang digunakan, kondisi lingkungan maupun besarnya partikel substrat. Pada Tabel 3 juga dapat dilihat bahwa produksi gula reduksi tertinggi yaitu pada periode pertumbuhan V. Kondisi ini terjadi karena pada periode $\mathrm{V}$ merupakan periode pertumbuhan tertinggi atau saat pertambahan miselium trepanjang, berarti ketika itu degradasi serat menjadi gula untuk pertumbuhan jamur sedang terjadi maksimum. Akibatnya gula reduksi sebagai hasil degradasi serat juga semakin tinggi. Dewi (2002) menyatakan bahwa produksi gula reduksi akan semakin tinggi sampai waktu tertentu kemudian menurun kembali. Pola produksi gula reduksi ini ternyata sama dengan pola pertumbuhan jamur yang ditandai dengan panjang diameter miselium dari koloni jamur. Mikroba dapat memecah serat menjadi gula sederhana karena dapat menghasilkan enzim lignase (Blanchete, 1994).

\section{Aktivitas Enzim LiP dan MnP (Lignase)}

Enzim yang berperan dalam pendegradasi lignin terdiri dari tiga jenis enzim yang biasa disebut enzim lignolitik, yaitu enzim lignin peroksidase $(\mathrm{LiP})$, mangan peroksidase (MnP) dan lakase. Namun yang sering diperhitungkan sebagai pendegradasi lignin yaitu LiP dan MnP. Aktivitas enzim LiP dan MnP dalam mendegradasi serat/lignin yang terkandung dalam media serat sawit dapat dilihat pada Tabel 4 .

Aktivitas enzim pada 4 hari pertama inkubasi tampak ektivitas enzim Lignin peroksidase maupun mangan peroksidase masih sangat rendah yaitu $1,05 \times 10^{-5}$ dan $2,56 \times 10^{-5}$,

Tabel 4. Aktivitas enzim LiP dan MnP dalam media serat sawit

\begin{tabular}{ccc}
\hline \multirow{2}{*}{ Fase Pertumbuhan } & \multicolumn{2}{c}{ Aktivitas Enzim } \\
\cline { 2 - 3 } & Lignin Peroksidase & Mangan Peroksidse \\
\hline I & $1,05 \times 10^{-5}$ & $2,56 \times 10^{-5}$ \\
II & $1,61 \times 10^{-5}$ & $5,58 \times 10^{-5}$ \\
III & $2,08 \times 10^{-5}$ & $7,81 \times 10^{-5}$ \\
IV & $3,04 \times 10^{-5}$ & $8,92 \times 10^{-5}$ \\
V & $5,91 \times 10^{-5}$ & $8,99 \times 10^{-5}$ \\
\hline
\end{tabular}


kondisi ini wajar karena jamur masih dalam pertumbuhan yang stagnan atau pada fase lag, semakin jamur tersebut bertumbuh ternyata aktivitas enzim juga semakin tinggi. Kondisi ini karena untuk pertumbuhannya, jamur memerlukan zat gizi yang diambil dari media serat dengan cara mendegradasi serat sebagai sumber nutrisinya. Pada hari ke-20 atau pada fase pertumbuhan $\mathrm{V}$ aktivitas enzim LiP dan MnP mencapai tertinggi, pada saat ini pula pertumbuhan tertinggi dicapai (Tabel 1 dan Tabel 4). Hasil ini menunjukkan sebenarnya jamur Marasmius sp. aktivitas enzimnya tidak begitu tinggi karena suatu jenis jamur dikatakan memiliki aktivitas enzim kualitatif yang tinggi apabila jamur tersebut bertumbuh dengan diameter koloni yang rendah tetapi enzim yang diproduksi atau aktivitas enzimnya besar. Artinya dengan biomasa yang sedikit mampu menghasilkan enzim dengan dengan aktivitas tinggi (Artiningsih, 2006). Namun demikian, sebagai sumber pakan untuk ternak biomasa jamur yang tinggi juga menguntungkan karena merupakan sumber gizi bagi ternak yang mengkonsumsinya, sehingga pertumbuhan koloni yang tinggi disertai aktivitas enzim yang tinggi akan lebih menguntungkan apabila digunakan sebagai sumber pakan ternak.

Pada penelitian ini tampak bahwa semakin lama inkubasi (sampai periode pertumbuhan $\mathrm{V}$ ) diameter miseliumnya semakin tinggi ditandai dengan miselium yang dapat menutupi cawan $(94,25 \mathrm{~mm})$ disertai dengan aktivitas enzim yang tinggi yaitu LiP $(5,91 \times 10-5)$ dan $\mathrm{MnP}$ (8,99x10-5) serta kandungan lignin yang rendah $(7,22 \%)$. Hasil penelitian juga menunjukkan bahwa aktivitas enzim lignase yaitu MnP dan LiP juga meningkat sesuai dengan produksi gula reduksi (Gambar 3). Kondisi ini menunjukkan bahwa serat sawit dapat diperbaiki nilai gizinya apabila difermentasi dengan jamur Marasmius sp. Sehingga serat sawit dapat dipergunakan sebagai sumber pakan yang berkualitas untuk ternak ruminansia.

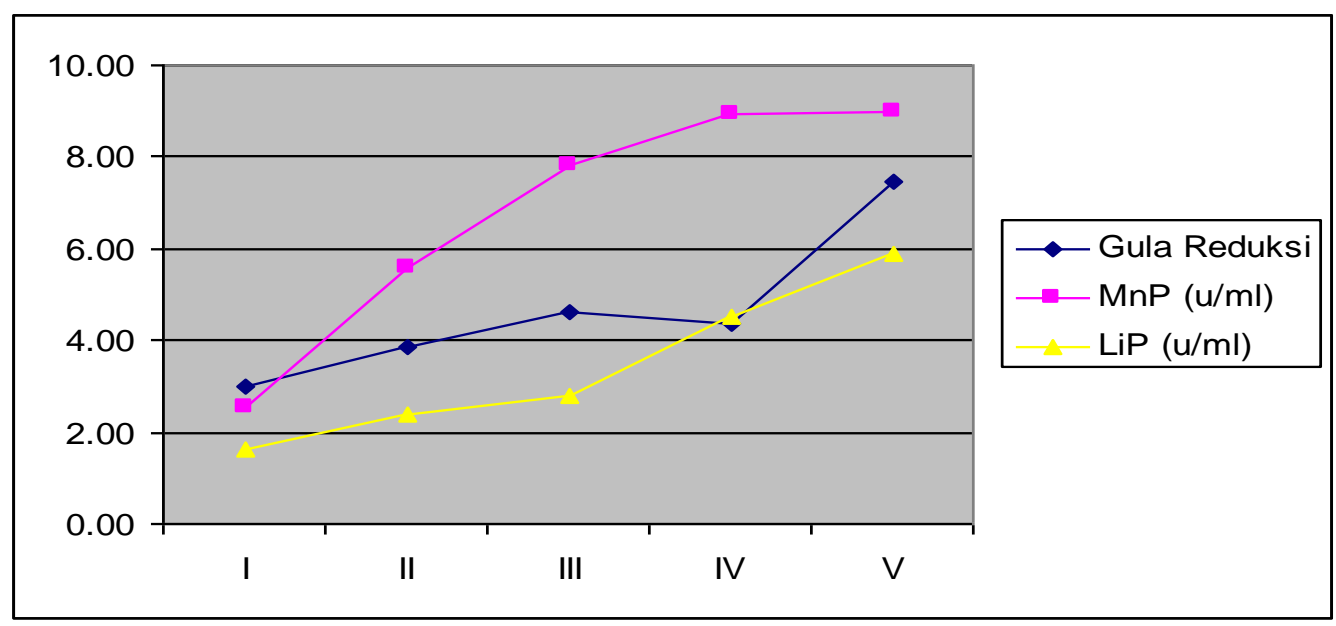

Gambar 3. Aktivitas enzim lignase dan produksi gula reduksi pada setiap fase pertumbuhan jamur 


\section{Kesimpulan}

Berdasarkan hasil penelitian dan pembahasan dapat disimpulkan bahwa :

1. Laju pertumbuhan jamur Marasmius sp. yang diukur setiap 4 hari terdiri dari 5 periode pertumbuhan dengan diameter terpanjang yaitu pada periode kelima

2. Kandungan gizi serat sawit terbaik yaitu pada periode pertumbuhan kelima

3. Kandungan lignin terendah yaitu pada periode pertumbuhan kelima dengan kandungan 7,23\%

4. Produksi gula tertinggi dicapai pada periode pertumbuhan kelima yaitu 7,485 mg/g subsrat.

\section{Ucapan Terima Kasih}

Terima kasih disampaikan kepada DP2M Direktorat Perguruan Tinggi yang telah mendanai penelitian ini, juga dihaturkan terima kasih pada Rektor Universitas Jambi dan Ketua LPPM Unversitas Jambi sehinga penelitian ini dapat terlaksana.

\section{Daftar Pustaka}

Artiningsih, T. 2006. Aktivitas lignolitik jenis ganoderma pada berbagai sumber karbon. Biodiversitas Vol. 7 (4):307-311

Blanchette, R.A. 1994. Degradation of the lignocellulose complex in wood. Can. J. Bot. 73:S999S1010.

Bonnen, A.M., L.H. Anton, dan A. B. Orth. 1994. Lignin degrading enzymes of the commercial button mushroom Agaricus pulmonarus. Apl. Environ. Microbiol. 60:960-965.
Camarero, S., B. Bockle, M. J. Martinez, dan A. T. Martinez. 1996. Manganese mediated degradation by Pleurotus pulmonarius. Appl. Environ. Microbiol. 62:1070-1072

Crawford, R.L. 1981. Lignin Biodegradation and Transformation. John Wiley and Sons, Inc. A Wiley-Interscience Publication, USA.

Dewi, K.H. 2002. Pengaruh pengecilan ukuran dan sumber limbah pertanian pada hidrolisis secara enzimatik. Akta Agrosia vol.5 (1):14-21

Eggins, H.O.W. and D. Allsopp. 1975. Biodeterioration and Biodegradation by Fungi. in Smith, J.E. and D.R. Berry (Eds): The Filamentous Fungi. Edward Arnold, Glasgow

Field, J.A., Ed de Jong, Gumersindo Feijoo-Costa and Jan, A.M de Bont. 1993. Screening for lignolytic fungi applicable to the biodegradation of xenobiotics. Trends in Biotechnology Vol. 11 No.2 (109):44-48.

Garraway, M.D. and R.C. Evans. 1984. Fungal Nutrition \& Physiology. John Wiley \& Sons, Singapore.

Harvey, P.J., G. F. Gilardi, M. L. Goble, dan J.M. Palmer. 1993. Charge transfer reaction and feedback control of lignin peroksidase by phenolic

compounds:significance in lignin degradation. J. Biotechnol. 30:57-69.

Hendritomo, H.I. 1995. Efektivitas jamur CULH (Colombia Unidentified Lignophilic Hymenomycetes) dalam 
mendegradasi lignoselulosa kayu albasia (Albizia falcataria L. Fosberg) pada berbagai sumber nitrogen dan konsentrasi Mn2+ yang dipersiapkan untuk proses biopulp. Tesis. Institut Teknologi Bandung.

Joetono. 1989. Degradasi Bahan Lignoselulosik Menjadi Kompos. Pusat Antar Universitas Bioteknologi Universitas Gadjah Mada, Yogyakarta.

Irawadi, T.T. 1990. Pemanfaatan limbah kelapa sawit sebagai media pertumbuhan kapang penghasil enzim extra selular. Fakultas MIPA IPB-Bogor.

Peels, J. dan K. Poutanen. 1989. The mechanism of enzymic hydrolysis of hemiceluloses (xilans) and procedures for determination of enzyme activities involved. $\mathrm{BFH}$ Institute of Wood IndustriesHamburg.

Reid, I.D. 1995. Biodegradation of lignin. Can. J. Bot. 73:S1011S1018.

Rusdi, U. D. 1992. Fermentasi konsentrat campuran bungkil biji kapok dan onggok serta implikasi efeknya terhadap pertumbuhan ayam Broiler. Disertasi, UNPAD-Bandung.

Santosa, U. 1996. Efek jerami padi yang difermentasi oleh jamur tiram putih (Pleurotus ostreatus) terhadap penggemukan sapi jantan Peranakan Ongol. Disertasi, UNPADBandung.

Sutedjo, M.M., A.G. Kartasapoetra, Rd.S. Sastroatmodjo. 1991.
Mikrobiologi Tanah. Cetakan 1. Penerbit Rineka Cipta. 